Péter Dolmányos

\title{
Present Buried in the Past
}

\author{
The Bog Poems of Seamus Heaney
}

\section{INTRODUCTION}

The bog poems of Seamus Heaney have been read and reviewed in different ways: admiration as well as strong negative criticism characterise the ambivalent reaction of critics to these poems. The fact that they have received such attention indicates their significance, yet the satisfactorily exact evaluation of this significance is still far from being complete. The bog poems are often not treated as an organic group of poems. It is true that they were not written as a group, yet they display features characteristic of a sequence of related poems (and there is even a booklet entitled Bog Poems, published in 1975, though it is absent from bibliographies). Taken together the poems read as a narrative, a myth, with a discernible narrative structure which shows the dynamism of the poems, reflecting Heaney's process of myth-making and his recognition of the problems inherent in this process: Heaney intends to provide the contemporary violence in Northern Ireland with a mythic framework for the attempt at explanation but as he proceeds he discovers the inherent limitations of his intention and deconstructs his myth, having found it impossible to explain the violence in any sensible way.

Ireland is a land of bog: the ubiquitous element of the Irish landscape is the peat bog. It is the heritage of the Ice Age - the glaciers of the Pleistocene eroded the whole land area of Ireland, stripping off not only the soil but the layers of younger rocks as well. Geographically the peat bog is a unique phenomenon: it 
is a watery place of coal formation. The bog as a form of inland water has an interesting characteristic: it takes in the excess precipitation and releases it when it becomes oversaturated. The bog is also a mysterious world with its seemingly bottomless pools which lend a haunting quality to the landscape itself as well as may serve some other purposes: they can swallow various things from butter to bodies of dead people. The bog preserves everything that falls into it and preserves them in a special condition - it is impossible to identify the age of items coming from the bog without scientific investigation. Time after time the bog "returns" these items though it needs human help - most often it is turfcutters who come across such findings.

The special nature of the bog offers certain metaphoric dimensions. The fact that it is a place of coal formation suggests a metaphoric meeting between fire and water, since the traditional source of energy in Ireland, in households, was peat. The preservative aspect of the bog renders it as a kind of living memory - it is "the memory of the landscape." The layered structure of the bog invites a parallel with history as the layers of the bog correspond to periods in history. Heaney focuses on these two aspects, the parallels with memory and history.

Heaney's interest in discovery, in quests of various kinds, or "digging" as he termed it, naturally brought him to the bog; the" early example of his fascination with the peculiar Irish element is the poem "Bogland." Still, the poem is only an excursion into the territory as the landscape is in the focus, the human beings appearing in the poem do not have a central significance yet. Heaney's encounter with P. B. Glob's book entitled The Bog People set him on a different course. Through the description of bodies found in Danish bogs the book revives an Iron Age culture in which there was a practice of ritual sacrifice aimed to secure the survival and thus the continuity of the community. The book fascinated Heaney greatly and provided him with an idiom adequate to the current conflict in Ulster. Interestingly enough, the book appeared in 1969, the date of publication coinciding with the beginning of the Troubles.

The common ground to Ireland and Denmark is provided by geography: both places abound in bogs. What really bridges the gap between the primitive ancient cult and the modern Ulster world is violence. The bog becomes an adequate metaphor in Heaney's treatment of the Troubles on this basis of similarity. The bog is also a means of distancing himself from the $20^{\text {th }}$ century

\footnotetext{
${ }^{1}$ Seamus Heaney. Preoccupations: Selected Prose 1968-78. New York: The Noonday Press, 1980, p. 54 .
} 
events. There is a different kind of sympathy towards the bog people than towards fellow sufferers in the crisis: as Declan Kiberd explains, it may be an attempt to "come to terms with the strange fact that readers, inured to newspaper photographs of daily atrocity, can feel more for the ancient than for the modern victim." This is based on a psychological motif: being exposed to violence over a longer period of time leads to the state of getting used to it, losing the threshold of the "normal" human level of empathy. Kiberd also mentions the idea of the victim of a sacrificial cult as the objective correlative of contemporary violence. ${ }^{3}$ The victims of the ancient cult are anonymous but they acquire the honour of being treated as individuals, whereas the victims of contemporary violence are often people familiar to him, still, they are nameless and come to be treated only later in In Memoriam-type poems published in the volume entitled Field Work.

As the bog poems are closely related to each other and form a sequence, a corresponding narrative structure can be identified, with sections of rising action, climax, falling action and resolution. "Bogland" is the introduction, a kind of prologue; "The Tollund Man" offers the exposition proper. "Come to the Bower" and "Bog Queen" represent the rest of the line of rising action. The two poems, "The Grauballe Man" and "Punishment" constitute the climax. The word climax suggests the moment of highest tension and also the change of direction - this is the moment when the realistic drive overcomes the mythmaking attempt of the poet. The last two poems, "Strange Fruit" and "Kinship," are the falling line, with the latter as the resolution. This pattern shows how the basic metaphor of the bog undergoes a change which may look to life for its analogue. The metaphor of the bog is born with the first poem. "The Tollund Man" gives vitality to it through the idea of invocation and this lends a symbolic quality to the motif and brings in the mythic dimension. As the goddess revives, the whole world of the bog starts a new life, the myth reaches "maturity." This is in this period that the bog motif starts to incorporate less elaborate elements: "atrocity" begins to balance "beauty." "Punishment" retains something of the mythic atmosphere but Heaney's stance is given in this poem which establishes the aesthetic consideration as the central element of the myth. In the last two poems the motif loses vitality in terms of the myth and "Kinship" concludes on the level of a contemporary report in the form

\footnotetext{
${ }^{2}$ Declan Kiberd. Inventing Ireland: The Literature of the Modern Nation. London: Vintage, 1996, p. 594.

${ }^{3}$ Kiberd, p. 594.
} 
of a poem; Heaney sheds the mythic dimension having recognised the impossibility of lending dignity to the sectarian killings of the $20^{\text {th }}$ century.

\section{POEMS: RISING ${ }^{4}$}

The bog story begins with "Bogland." This is the poem to set the scene: it shows an environment which is endless in both horizontal and vertical dimensions. The endlessness is a distinct quality and the vertical dimension acquires a special significance as the poem progresses towards its conclusion which implies a metaphoric tradition, based on the idea of the continuous growth observable in the bog.

The poem opens with a comparison of Ireland with the "prairies," and though it expresses an absence, the negative statement is turned into an assertion by the following sentence: "Our unfenced country / Is bog." This country is endless, it is "unfenced" - an island, bordered only by the sea; the inner border dividing the Republic from the United Kingdom seems ignored, or at least it is not referred to as relevant in the context since the elements of physical geography do not conform to political borders. The bog "keeps crusting / Between the sights of the sun," it becomes thicker as the time passes, there is a continuous expansion in the vertical dimension. This vertical dimension is focused upon in the main section of the poem: the motif of digging is brought in as the people are shown engaged in an activity of excavation: "Our pioneers keep striking / Inwards and downwards." The word "pioneers" carries the idea not only of the turf-cutters but that of a different group of "diggers," the poets, of whom Heaney is one representative. The bog is built up of layers, and each layer is a part of history as "Every layer they strip / Seems camped on before," and in this way the present is understood as just one of the layers. This layered structure suggests a kind of continuous enrichment, even a tradition, if the bog is understood as the memory of the landscape. The direction of the exploration is towards the centre but "The wet centre is bottomless." The vertical dimension is endless, and the centre is "wet" and not a realm of fire, suggesting preservation rather than consummation, which foreshadows later elements of the bog motif. The phrase "Atlantic seapage" may be interpreted as a reference to something greater, something of a larger

\footnotetext{
${ }^{4}$ Quotations from the poems are taken from the following collections: Seamus Heaney. New Selected Poems 1966-1987. London: Faber, 1990; Seamus Heaney. North. London: Faber, 1975; Seamus Heaney. The Spirit Level. London: Faber, 1996.
} 
scope, something which is common to a greater number of participants. In this sense the word "Atlantic" is a reference to Northwest Europe and in such a way it is a potential seed of the myth of the North.

As Heaney himself explained it, the poem was born out of a drive to establish a kind of connection between the forces shaping his consciousness: "I had a tentative unrealised need to make a congruence between memory and bogland and, for the want of a better word, our national consciousness." ${ }^{5}$ The idea of the bog was a haunting presence but the immediate influence, the decisive impetus came when Heaney, teaching modern literature in Belfast, read about the notion of the frontier, the American myth of the west. The bog offered itself as the adequate Irish myth, as this is a common basis for North and South alike, without divisions. The landscape is in the focus of the poem; the human figures who appear are simply agents for the sole purpose of revealing the unique preservative feature of the bog; they are contemporaries, alive and have no mythical significance.

The first "real" bog poem is "The Tollund Man," real in the sense that it is based on Glob's findings and deals with one of the ritual sacrifices emerging from the lost world of the Iron Age. The poem takes a personal perspective as Heaney takes the framework of a potential pilgrimage to Aarhus, where the Tollund Man is displayed. The idea of a journey to see the victim of a sacrificial cult is complemented by an invocation and the bringing together of the distant worlds of Iron Age Jutland and contemporary Northern Ireland.

The first section of the poem is the declaration of Heaney's intention for the pilgrimage and a description of the Tollund Man. The idea of pilgrimage is reinforced later by images such as "a saint's kept body," "consecrate," "holy ground" and "pray." The motifs describing the man create the sense of innocence as the attribute of the figure and the indication of his death constructs the picture of a ritual. The basis of the ritual is a fertility cult or religion which meant choosing a bridegroom each year for Nerthus, the Mother Goddess of the Earth, a North European equivalent of fertility goddesses of the Mediterranean region, Ishtar and Aphrodite; ${ }^{6}$ this bridegroom was ritually murdered and thrown into the bog, the dwelling place of the goddess. The aim of the ritual was to secure the fertility and renewal of the territory, and by this way to maintain continuity.

\footnotetext{
${ }^{5}$ Heaney. Preoccupations, pp. 54-55.

${ }^{6}$ Michael Parker. Seamus Heaney: The Making of the Poet. Basingstoke: Macmillan, 1993, p. 106.
} 
The second section of the poem elevates the Tollund Man to the level of sainthood, though Heaney feels he "could risk blasphemy" by this. Still, the aim is noble: the ancient man is supposed to germinate "The scattered, ambushed / Flesh of labourers" to renew life in Ireland. This is Heaney's invocation to the "Bridegroom to the goddess." The myth of the waste land also appears as a hint, as a parallel to the fertility cult. The labourers mentioned in these lines turn out to be corpses laid out in a farmyard - it is a reference to a conflict between the English and the Irish in the 1920s when Protestant paramilitaries killed four Catholic brothers. The event was well-known to Heaney, "part of the folk-lore of where I grew up", as he put it.' The gap between the distant past of the Iron Age and twentieth-century Ulster is diminished and bridged at once by this reference. Still, there is a suggestion by Parker that the Iron Age ritual is almost "civilised," since these killings "at least could claim the dignity of religious purpose," 8 whereas the action of the Protestant paramilitaries is a mere act of meaningless violence. This idea is strengthened by the fact that the death of the Tollund Man is described with simple nobility whereas the death of the four young brothers is shown with elements of brutality, which creates a shocking picture of violence in the twentieth century.

The last section of the poem establishes a different kind of connection between the worlds separated by thousands of years yet connected by manifestations of violence: the distance is further reduced by the immediate relationship between the pilgrim Heaney and the land: "Something of his sad freedom / As he rode the tumbril / Should come to me, driving." Even if there is a great difference between the voluntary act of pilgrimage and the involuntary one of being sacrificed, the imaginative parallel could lead to an at least partial sharing of the experience. The picture is constructed in the dynamics of progression and regression: the section opens with a sharing of the experience, then the scene moves back into the perspective of a stranger in a foreign land and returns to near familiar intimacy through the concept of "home":

Out there in Jutland

In the old man-killing parishes

I will feel lost,

Unhappy and at home.

${ }_{8}^{7}$ Quoted by Parker, p. 107.

${ }^{8}$ Parker, p. 107. 
The majority of the bog poems were published in the volume North. This collection of poems has been seen as the book that attempts to create a myth, a bridge between past and present. The first among the bog poems of the volume is "Come to the Bower." This poem deals with the finding and uncovering of the body of a woman in the bog. The motif of exploration is present though this time it is not in the form of digging but it is "unpinning" and "unwrapping." The poem begins with the descrivion of the scene which appears as a typical "love nest." The body found there is that of a noble woman, she is a "dark-bowered queen," her social status is indicated by "A mark of a gorget in the flesh / Of her throat." The body is attributed the state of "waiting," which suggests sleep rather than death. At the moment of "unwrapping" something significant happens: "And spring water / Starts to rise around her." "Waiting" acquires its full meaning in this context - the dormant state comes to an end with the moment of her discovery. The word "spring" itself has implications of rebirth. This is enhanced by the image of the water starting to rise, and the picture created is that of a new existence initiated by having been found and excavated.

The phrase "dark-bowered queen" in the second stanza establishes the identity of the woman by a metaphoric reference to Mother Ireland. The suggestion of the theme of rebirth supports this viewpoint, together with the scene of the love-nest and the social status of the woman. Heaney's rather private approach may be interpreted as his wish of personal involvement in the process of the revival through an "imaginative intercourse with his country." On another level "Come to the Bower" is a revival of the bog theme, as it was put aside with "The Tollund Man" and brought back with this poem first, and the "rise" of water suggests a process not fully under Heaney's control, which foreshadows the later development of the motif.

The poem "Bog Queen" looks at the special existence of one of the bog people from the inside. The persona of the poem is the bog queen herself; the account is given in the first person singular, describing all the processes to which the body had been subject until it was found and excavated. The story of decay is paralleled with and partly muted by that of a long existence of a different kind, the "life" after death interpreted with the concepts of the living; this can be justified by the resurrection of the woman at the end which suggests a kind of dormant and waiting state rather than the void state of death. The end of the

\footnotetext{
'Edna Longley. “'Inner Emigré' or 'Artful Voyeur'? Seamus Heaney's North.” In: Michael Allen, ed. Seamus Heaney. Basingstoke: Macmillan, 1997, p. 48.
} 
poem evokes glory as the moment of finding the body and the beginning of the excavation are elevated on the level of rising, offering an metaphoric connection with the theme of invocation in "The Tollund Man."

The very first stanza compresses some of the main elements of the poem "waiting," "turf-face" and "demesne wall." The past tense opening the poem suggests a change of state and the "I lay waiting" of the first stanza becomes the "I rose" of the last one as the theme unfolds. The scene of waiting, "between turfface and demesne wall" indicates the meeting point of nature and civilisation. The once noble world suggested by the word "demesne" is gone, it is overgrown with vegetation, and the former "queen" lay "between heathery levels / and glasstoothed stone."

The description of the body begins in the second stanza. The body "was braille / for the creeping influences": this creates the vision of a communion between the body and the elements of nature surrounding it. The elements of nature mentioned are shown being engaged in activities of exploration such as "groping" and "pondering," or of subjugation as "digesting." The opening line is repeated in the fourth stanza to enhance the concept of this strange existence: despite the seemingly subdued state she is not defeated, the process of decay does not destroy her entirely. The brain is likened to "a jar of spawn," which gives hints about a new existence through the word "spawn." Images of physical decay follow but the process seems to be constrained by some mysterious force: the "diadem grew carious," still, it is preserved in the bog. Her "sash was a black glacier / wrinkling," but it is still there at when she is found. Her discovery is a matter of chance as a turfcutter comes across the body; the finding is reburied but she emerges out of her hiding place following an incident diminishing her appearance to a certain extent:

$$
\begin{aligned}
& \text { and I rose from the dark, } \\
& \text { hacked bone, skull-ware, } \\
& \text { frayed stitches, tufts, } \\
& \text { small gleams on the bank. }
\end{aligned}
$$

This is a moment of resurrection after the long state of waiting; the concept of "rising" suggests the attributes of a divine existence.

The poem may be read as a variation on the theme presented by the preceding poem. In that work the finding of the woman is described, in this the woman is hypothetically given the opportunity to speak. The point of view of the buried woman is introduced and she gives a detailed and vivid account of her 
existence suspended between the two worlds of life and death. There is an identity for the woman: she is the incarnation of Nerthus, the goddess coming alive again, but she can also be an incarnation of the "dark-bowered queen" of Ireland, the present calling for new sacrifices. The change of perspective allows a different relationship with the reader, a more immediate one; the confession-like quality of the poem reflects Heaney's drive for mythicising at its most intensive moment the intention of Heaney to find a mythic framework is reflected in the intention of the woman to come alive again and to haunt the living with her constant need of sacrifice.

\section{POEMS: CLIMAX}

"The Grauballe Man" is another account of a man who was sacrificed as part of the fertility religion. If "The Tollund Man" is a pilgrimage, "The Grauballe Man" is the arrival, the celebration of being there, in the interpretation of Edna Longley. ${ }^{10}$ However, as the ending of the poem suggests, the closer perspective creates a standpoint which is not celebratory at all, and a new direction begins with this poem, a direction which leads towards the revision of Heaney's standpoint in relation to finding a possible mythic framework for the violence.

The images used to describe the body in the opening part of the poem build up a vivid picture of metaphoric union between the man and the bog. The references of "tar," "pillow of turf," "black river," "bog oak," "swans's foot," "wet swamp root," "mussel," "mud" and "elderberry place" evoke a world dominated by dark colours and water. The man is described in terms of the bog itself, the union between them is that of a peaceful harmony as the man is seen lying on a "pillow." The impression of this peaceful scene is capsized in the fifth stanza when the "slashed throat" of the man is mentioned: the peaceful image of sleep is turned into the fearful picture of violent death. Owing to the wound on the throat the head looks like a helmet of which "the chin is a visor," bringing the implications of a warlike culture. Heaney's reaction to the sight is equally ambivalent. The "vivid cast" does not allow the designation "corpse" and it is not even a "body" though the "opaque repose" dims the strength of the fascination of the observer.

The face of the Grauballe Man is mentioned for the first time only in the eighth stanza. The description of the man becomes round with his "twisted face"

${ }^{10}$ Longley, p. 43. 
and the actuality of terror asserts itself. The picture is a more balanced one as the Grauballe Man is finally "hung in the scales / with beauty and atrocity" and "with the actual weight / of each hooded victim, /slashed and dumped." "Beauty and atrocity" construct the complex of the Kantian sublime as they combine to awaken an ethically more balanced response in Heaney; the appearance of "atrocity" is an important new development in the evolution of the motif. The last three lines of the poem connect the present with the past through an implicit reference to the methods of the IRA: the name of the organisation is never mentioned but the "hooded victim, / slashed and dumped" marks the method of execution employed by the Republicans, as well as by the Iron Age community.

The body is described to perfection, though this time there is not the kind of voice present as in the case of "The Tollund Man." There are details which show Heaney's exuberance but the indication that his throat was cut brings the victim closer to a de-mythicised existence. Still, it is not a corpse, not even a body, it is something sublime, rather, even if there are no references to sainthood and a possible salvatory germination of the land in hope of a better future. The conclusion of this poem is also different as the Grauballe Man is viewed from a less prejudiced point of view: the eagerness to maintain the myth-making strain at the sight of this man is balanced by the recognition of the terror and pain reflected on the face. Whereas "The Tollund Man" is a record of an experience giving birth to invocation, "The Grauballe Man" is the moment of clash between "beauty and atrocity," myth and reality, suggesting an important turning point in the use of the bog motif.

"Punishment" is a bog poem of a different kind. The central figure is a woman but she is not the incarnation of Nerthus. The young woman was not a cultic victim: she was executed for having committed adultery, she is the "victim" of capital punishment. The perspective is again somewhat ambivalent as there is sympathy awakening in Heaney but his reaction does not reflect this: however strong the sympathy felt for the girl is, he confesses that he would have stood there dumb and watched her execution. The generalised remark at the end, the similarity in fate with girls going out with British soldiers (shaved, tarred and feathered) gives a current reference to the poem and opens a new direction of correspondence between past and present.

The opening sentence carries enough empathy for Heaney to share in the experience of execution described through tactile images. The third stanza moves away from the immediacy of personal contact and creates the sense of distance 
which gives him a perspective to describe the body. The description is done in a similar way as in other bog poems - the points of reference are elements of the world of the bog. The first suggestion of the reason of her death comes in the fifth stanza but the picture unfolds only in the one that follows it; there her status is identified as a "little adulteress." The word "little" serves a dual purpose as it takes something away from the edge of the statement and also maintains a personal overtone which is supported by the pronouns: the girl is referred to as "you" instead of the more distant "she" of the earlier stanzas.

She is seen as a "scapegoat," someone to whom evil was transferred, and Heaney's sympathy is expressed by the word "poor." He intensifies the picture by stating "I almost love you" just to confess that his reaction would have been the same as those who were present at her execution: "but would have cast, I know, / the stones of silence." The sympathy is muted as the shadow of reality moves over the scene, and Heaney once again steps into a more objective distance, asserting his role of an "artful voyeur."

Heaney's reaction is that of a man used to the proximity of violence. It is even typical of $20^{\text {th }}$ century city dwellers, his compassion is silent and therefore passive, it is that of a private man not inclined to show it to the external world. The explanation for such behaviour is attempted in the last stanza:

$$
\begin{aligned}
& \text { I [Heaney] } \\
& {[\ldots]} \\
& \text { who would connive } \\
& \text { in civilized outrage } \\
& \text { yet understand the exact } \\
& \text { and tribal, intimate revenge. }
\end{aligned}
$$

This stanza appears to have posed a problem for interpreters as the somewhat diverse critical reception indicates. Seamus Deane sees this as the dilemma of outrage and revenge, that the answer is imaginatively revenge, morally outrage; ${ }^{11}$ this is the dilemma which is echoed by most of the commentators. Heaney's own comment is basically a prose paraphrase of the conclusion of the poem: "At one minute you are drawn towards the old vortex of racial and religious instinct, at another time you seek the mean of humane love

${ }^{11}$ Seamus Deane. "Seamus Heaney: The Timorous and the Bold." In: Michael Allen, ed. Seamus Heaney, p. 70. 
and reason." 12 The stanza reflects the tragic dialectic of the situation - the divergent forces at work allow for no reconciliation, there is no possible way of bringing them together even by splitting the self into two schizophrenic parts. Heaney chooses the only way out by banishing himself into the position of the "artful voyeur," at once establishing and emphasising the primacy of the aesthetic principle in his use of the bog people in his treatment of the contemporary conflict.

The image of the "betraying sisters" establishes the connection with the present. It also serves as the precedent to his hypothetical silence during the execution of the girl. In the concluding stanza his "civilized outrage" competes with "understanding" and the latter outweighs the former, indicating Heaney's standpoint. This moment is often considered as Heaney's taking sides. The decision of Heaney, however, is an emotional one rather than an intellectual one - he is the member of a community and speaks as such. The conditional form takes something away from the edge of his choice and the contradictory idea of "civilised outrage" has a similar effect. Together with the concept of the "artful voyeur" these all suggest Heaney's wish to stay outside the conflict.

Heaney's ambivalent relationship with the figure is shown in the changes of perspective in the poem. His personal involvement takes the form of tentative identity at first. From this standpoint he moves into a distance to draw the picture of the girl; the climax of this movement is the word "adulteress." With the reawakening of sympathy he moves closer again to address the girl as "you." From here the poem goes on to reach a resolution which is a confession of his position as an outsider, a "voyeur." These changes of perspective create a pulsating movement which, together with the idea of the "artful voyeur," lends a climactic quality to this poem in the sequence.

\section{POEMS: FALLING AND RESOLUTION}

"Strange Fruit" is another poem dealing with a woman found in the bog. This time the viewpoint of the persona is more distant, there is not the same kind of deep sympathy felt for the victim as before and the idea of attraction is totally missing. The trove is only the head and this head is repulsive as it is described in a more naturalistic way lacking any kind of consolatory elements. The poem begins

${ }^{12}$ Quoted in Blake Morrison. Seamus Heaney. London: Methuen, 1982, p. 64. 
with the description of the head with images related to plants - "gourd," "pruneskinned," "prune-stones for teeth" and the "wet fern of her hair"; these create the almost usual bog atmosphere. The picture becomes less attractive when her nose and eyes are mentioned: "Her broken nose is dark as a turf clod, / Her eyeholes blank as pools in the old workings." The conclusion of the poem is markedly different from those of the earlier poems:

\section{Murdered, forgotten, nameless, terrible \\ Beheaded girl, outstaring axe \\ And beatification, outstaring \\ What had begun to feel like reverence.}

The sight "outstares" Heaney's attempt to elevate the bog people to a mythic level, and in this way to colour the present violence with a hue of acceptability; the rational part of his mind overcomes the myth-maker. The body found in the bog is now a mere document of ancient violence, no indication of myth is present.

This poem represents a departure from the earlier pattern in another way as well: it is written in a sonnet form but it is a failed sonnet. The form suggests another attempt at aestheticisation but it is an attempt of a different kind; Heaney breaks with the short lines of the other poems. The "failure" of the form also indicates the different direction the bog poems after "The Grauballe Man" and "Punishment" are to take; Heaney deliberately misses rhymes, the line length is inconsistent, the iambic pentameter is distorted - these all point towards and reinforce the recognition in the conclusion of the poem.

"Kinship" is a return to Ireland, it is a symbolic homecoming after the bog poems of distant countries. The bog is revisited and re-examined, and in many ways it is a summing up, a reconsideration, supplemented by the element of confession. In this way this poem may be seen as the concluding piece in the row of the poems dealing with the bog - the theme has been used and exhausted from the point of view of the possible references.

The poem is divided into six sections, each of which develops a smaller theme within a larger pattern, that of the exploration of the bog, physical and spiritual at the same time. There is an element of confession in the first section in which Heaney sets out on an imaginary journey in his native bogland. The very first stanza establishes the "kinship" between Heaney and what is in the bog: 


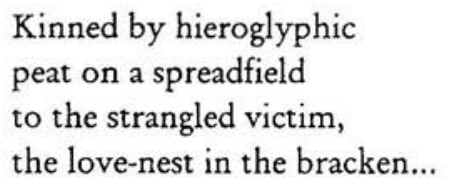

The bog relates the "strangled victim" to Heaney as a "kin." The peat is "hieroglyphic," which suggests something to be deciphered, a hidden message in connection with that victim; this is also a reference to the basis of the bog motif. The line "I love this turf-face" opens the elaboration of the elements of his fascination with the bog. This mysterious world is at the same time a dangerous one as "each open pool" is "the unstopped mouth / of an urn, a moon-drinker."

The second section opens with the enumeration of the "slime kingdoms." These are worlds of cold, mud and dirt, even the ring of the words denoting them seems to echo their characteristic features. Bog, however, is something different for Heaney as he tastes the word, feeling its Gaelic roots: ${ }^{13}$ "But bog / meaning soft, / the fall of windless rain." There is another important distinction implied concerning the relation of these lands to life. The "slime kingdoms" are populated by the "cold-blooded," there are only "mud pads" and "dirtied eggs" to encounter; life manifests in forms generally considered as repulsive (the world of reptiles). As a contrast, the world of the bog itself is a living organism whose different organs are referred to as "Ruminant ground" and "deep pollen-bin," the former associated with digestion and the latter implying fertility.

The bog is turned into a multi-faced world in the stanzas of the section. It is first a "store house" and a "necropolis," 14 as the kenning-like phrases of "Earthpantry, bone vault, / sun-bank" imply. In the first line of the fifth stanza the bog is personified: it is "Insatiable bride," made identical with Nerthus, the Mother Goddess of the Earth. The final image of the bog is deeply personal and put into the context of Heaney himself: it is "nesting ground, / outback of my mind." This opens a different perspective as the landscape is internalised, seen as both the soil of creative imagination and an "outback," a less comforting part at the same time.

The third section brings images of a different kind. This section has sexual references as the images employed point towards an intimate relationship between Heaney and his native ground. The spade evokes the motif of digging, and as he raises it out of its hiding place the bog opens in a simultaneous process. The

\footnotetext{
${ }^{13}$ Parker, p. 139.

${ }^{14}$ Parker, p. 139.
} 
process of uncovering the spade in the first stanza leads to another uncovering with the intercourse between spade and ground. The private discovery of Heaney is complemented by another, carried out by others but influencing his consciousness to a great extent. The finding echoes the first two bog poems of the volume as it is a woman figure and Heaney comments on the historical perspective: "I stand at the edge of centuries / facing a goddess." The fertility cult of the Iron Age is the referent of these lines: the "cloven oak-limb" is a representation of the goddess, lying under the "cairn," a heap of stones indicating a burial site; Heaney alludes here to Glob. ${ }^{15}$ The myth of another land is seen as a "twin" to his own "obelisk" of the spade, which allows an interpretation of Heaney's "digging"-type poetry as myth-making, creating the myth of Ireland.

The next section opens on a different tone. The first line is an antithesis of Yeats's "The Second Coming" where "Things fall apart; the centre cannot hold." Heaney's Bogland is different, this is a world where the wet centre of the bog is a solid basis: "This centre holds." The centre also "spreads," and the bog is depicted as a world where life and death are seen as close neighbours as the bog itself is "sump and seedbed, / a bag of waters / and a melting grave." The cycle of seasons in this natural world is introduced by autumn. This is a period of decay but that of renewal follows during which the plants in the bog ensure their continuity. Elements of nature "deepen their ochres" in one season but in the other there is abundant fertility as "Mosses come to a head, / heather unseeds." The picture is peaceful and inviting until the last line of the fifth stanza; there the word "rots" brings back the sense of a more sober reality into the almost idyllic vision.

The last stanza is an explicit statement of Heaney's relationship with that world: his origin is identified as his roots have been found, accepted and understood:

$$
\begin{aligned}
& \text { I grew out of all this } \\
& \text { like a weeping willow } \\
& \text { inclined to } \\
& \text { the appetites of gravity. }
\end{aligned}
$$

Despite the assertion of his being subject to the "appetites of gravity," Heaney turns towards the mythic again in the fifth section. The myth of the fertility ritual is brought back at the level of suggestion through the image of "The hand-carved felloes / of the turf-cart wheels." The "tawny rut" of the third section may also be

${ }^{15}$ Cited by Parker, p. 140. 
seen as made by the vehicle on which the victim travelled to meet his death in the Iron Age, which links the two sections on this thematic level.

The last section is a report on the state of affairs in late twentieth-century Ulster. There is an apostrophe to Tacitus, the ancient historian documenting the customs of the old inhabitants of Britain and Germany. He is called in as a witness to the present-day life in Ulster, to assist Heaney in his account of this "troubled" land. The reference to Cathleen Ní Houlihán opens the description of the violent present: "Our mother ground / is sour with the blood / of her faithful." After the "mothers of autumn" in the fourth section it is now the ground which receives the "mother" designation. Meanwhile "the legions stare / from the ramparts" - this is a sad picture of people killing each other while the army is standing by and watching the events; it could refer as much to the Roman legions of the time of Tacitus as it refers to the British army as a witness of the Troubles in Ulster.

The ancient historian is invited back to the "island of the ocean" to see twentieth-century history in the making. The question Yeats asked in the poem "Easter 1916" ("O when may it suffice?") is answered by a disillusioned Heaney: "nothing will suffice." What seemed tentative for Yeats is a certainty for Heaney sixty years later. The account of the situation has horrific elements:

Read the inhumed faces

of casualty and victim;

report us fairly,

how we slaughter

for the common good

and shave the heads

of the notorious,

how the goddess swallows

our love and terror.

The closeness of violence compels Heaney to ask the help of a more experienced witness whose detached standpoint is more adequate for the task of reporting. "Report us fairly" is his request and the syntax is somewhat ambiguous - the audience is either not specified or it is the same community whose acts are to be reported. Heaney also gives his short report which is full of parallels between the present and the Iron Age as far as the phenomena are concerned: the 
faces of "casualty" and "victim," the "slaughter / for the common good," shaved heads and the "goddess" establish the connection once again between the world of the Ulster Troubles and the civilisation of the Iron Age. This connection, however, is different from the one implied in the early poems as the personal contact present there cannot be retained in this poem and the consolatory elements of the bog in the opening sections are outweighed by the picture of violence at the end.

The idea of the "slaughter / for the common good" could be seen as justification and legitimisation of the violence of the present, however it is rather a rendering of the general understanding of the situation into words without identifying with it, providing even a somewhat ironic overtone by the concept of the "common good." The line "Nothing will suffice" is not only an answer to Yeats's question but an important moment for Heaney himself as it deconstructs the hypothetical element of hope in "The Tollund Man": there is no germination, there is no sainthood involved; there is only pointless and endless violence totally pointless as the quotation implies. There is no myth here; it is the perspective of the historian that is required to treat the barbaric present.

\section{PREIENT BURIED IN THE PAST: SURFACE AND UNDER THE SURFACE}

The idea of the bog as a kind of collective memory is the discovery which facilitates Heaney's use of the bog myth. The layers of the bog correspond to periods in history, which means that the present is just one among these layers. The present is not a unique one, the only distinct feature is its contemporaneity, that it is the "layer" which is immediately accessible for the poet. Immediate accessibility, however, does not necessarily mean the success of interpretation. It is because of the problematic status of the interpretation of the present that Heaney turns towards the special world of the bog and grabs the opportunity of utilising it, as an objective correlative, for his attempt to come to terms with troubled situation of the present.

The findings in the bog offer the basis of similarity between the present and the past. In such a way some of the basic patterns observed in the present can also be seen in the culture of earlier times. The common elements are the violence and the religious element which is in strong connection with the notion of territory. The leading motif is the unintelligibility of the presence of violence, its state of being beyond the rational, connected to faith and beliefs, and in such a 
way defying explanation and justification. The past is not seen as an explanation in the rational sense of the word; it is simply a precedent, an example of having happened before, creating the impression as if some aspects of the present had been buried in the past (violence, beliefs, irrationality). In this way the past is something that can be explored and discussed without openly taking sides in the conflict of the present.

On the surface level the bog poems deal with human characters. These figures featuring in the poems can be classified as belonging to two major, and at the same time basic, groups: there are female and male characters. The male ones are the representatives of a horrible though noble status: they are bridegrooms to the goddess, victims of the cult, and as such, Heaney attributes a sublime quality to them. The female characters are different ones as they can be put into two groups. The first group is that of the Bog Queen herself; she is an incarnation of the goddess, Nerthus. The other group consists of two figures: an adulteress and a beheaded girl, though there is no reference to the way how the latter came to be beheaded. The more important representative of this latter group is the girl in "Punishment." She has a different place in the myth, which raised points frequently commented on - the moral dimension of Heaney's reaction has been understood as his taking sides yet he does little more than gives voice to the basic dilemma of the necessity of reaction in situations of conflict.

One of the female types is the goddess whose name is Nerthus in the Northern European cult. She has an equivalent in the cultural context of Ireland: it is a female power referred to as Mother Ireland, Cathleen Ní Houlihán or the Shan Van Vocht. ${ }^{16}$ As Nerthus, the goddess of the Danish bog people is a goddess requiring annual sacrifice, Cathleen is also demanding: her "material aspect," the bog is termed "insatiable bride" by Heaney. Whereas Nerthus is pleased by rituals of sacrifice in which people present their offering as a natural and usual constituent of their culture, Cathleen is a different figure, she is more difficult to satisfy: time after time she calls for sacrifice. History proves this, and Yeats's question, "O when may it suffice?," is directed at this phenomenon. This is generally interpreted as the basic idea of Republicanism in the North.

There is a similarity observable in the figures of the bog poems on the level of description, yet at the same time they retain their individuality. The Tollund Man and the Grauballe Man are described in similar terms, though the description of the latter is more detailed. It is the face which sets them apart - it is

\footnotetext{
${ }^{16}$ Heaney quoted by Parker, p. 134.
} 
"stained" in the case of the former and "twisted" in the latter. The female figures also show some similarities; this is apparent in the case of the poems "Come to the Bower" and "Bog Queen," where the "heroines" are the incarnations of one and the same person. There is a similarity in terms of description between the "queens" of the bog and the female victims too. Heaney uses the same set of images to create his verbal "photographs" of the bodies, which means the repetition of patterns. The idea of these repetitions may be seen as an attempt of reinforcement, a deliberate intention to reinforce the concept of kinship, both within the community whose members have been found and also on a larger scale, between the group of human figures and nature. However, to a certain extent, this method results in over-use and tends to weaken the effect of the picture on the reader; Heaney's recognition of this leads to a subversion of the motif in the later poems.

Under the surface level of the people of the bog there are discernible traits of deeper considerations. Though Heaney is interested in the figures themselves, these motifs have a greater significance. As Heaney comments on this, "the gaze which the poems fix upon these Iron Age bodies is haunted by parallels which they evoke with things that were happening in Northern Ireland during the violent days of the 1970s." ${ }^{17}$ The bog poems tackle the problems of origin and identity, history, landscape, and the most apparent theme is politics in which all the other elements meet and merge.

It is in the volume North that the political strain of Heaney's poetry manifests in an open form. It appears in his poetry earlier than this but there is no such extension of it as in this collection. In the motif of the bog the private and the public dimensions meet: Heaney's private exploration reaches the point where it intersects the sphere of public affairs; his own origin and identity come to be interfused with the history and the landscape of his country. As the bogland was, with Heaney's words, a "genuine obsession" from childhood, ${ }^{18}$ it seems almost inevitable that Heaney should have come to the bog as a world to explore.

${ }^{17}$ Seamus Heaney. Stepping Stones. London: Penguin-Faber Audio Books, 1995, side A ("The Tollund Man").

${ }^{18}$ Quoted by Parker, p. 7. 


\section{PRESENT BURIED IN THE PAST: IMPLICATIONS AND VALIDITY}

The elements that allowed Heaney to use the world of the bog people as a symbol in his interpretation of the contemporary world of Northern Ireland are violence and religion. Heaney gives an account of this common ground in an interview:

You have a society in the Iron Age where there was ritual blood-letting. You have a society where girls' heads were shaved for adultery, you have a religion centring on the territory, on a goddess of the ground and of the land, and associated with sacrifice. Now in many ways the fury of Irish Republicanism is associated with a religion like this, with a female goddess who has appeared in various guises. She appears as Cathleen ni Houlihan in Yeats's plays; she appears as Mother Ireland. I think that the Republican ethos is a feminine religion, in a way. It seems to me that there are satisfactory imaginative parallels between this religion and time and our own time. ${ }^{19}$

The Troubles in Northern Ireland then may be understood as a kind of "fertility cult" - a forced and rather violent way of bringing about a new existence. The notion of Cathleen Ní Houlihán provides support for this: there is a goddess for Ireland, an artificially preserved pagan trait in the context of Christianity. There is sacrifice involved in the cult of Cathleen too. Questions may arise concerning the necessity of the sacrifice and also about the idea of the sacrifice as a kind of "germinating" the waste state of divided existence, whether it is a kind of resolution of a historical situation which divides and separates two segments of the same people. The question of a separate Northern Irish identity also emerges: whether there is such an identity or it. is the case of British versus Irish. This direction leads to the domain of cultural identity and away from the poems themselves, still it is among the implications of the bog motif.

If the bog is accepted as an analogue, then the violence is interpreted as being within the community. This suggests unity, oneness, pointing towards a unified existence. Still, sectarianism brings in elements of difference in the form of different communities - the source of the conflict is externalised by putting it beyond the border. This is rather a political conflict transferred to the domain of religion and culture. Heaney has also come to this point, though only after his move to the Republic: "I always thought of the political problem - maybe because I am not really a political thinker - as being an internal Northern Ireland division.

${ }^{19}$ Quoted by Morrison, p. 63. 
I thought along sectarian lines. Now I think that the genuine political confrontation is between Ireland and Britain., ${ }^{20}$

The world evoked and revived by the bog poems is a world where myth plays an important role, as it is exemplified by the sacrificial ritual itself. Deane points out that "although it is true that the Viking myths do not correspond to Irish experience without some fairly forceful straining, the potency of the analogy between the two was at first thrilling." ${ }^{21} \mathrm{He}$ is the only one among critics who discovers the development observable in the treatment of the theme, a development which shows a growing uneasiness in providing the mythic dimension to violence of any kind.

Other critics have pointed out the unsatisfactory quality of the myth. Ciaran Carson is one of those who attack Heaney on such a ground. He accuses Heaney of having "become the laureate of violence" through the myth. ${ }^{22}$ "[Heaney] seems to be offering his 'understanding' of the situation almost as a consolation ... It is as if he is saying, suffering like this is natural; these things have always happened; they happened then, they happen now, and that is sufficient ground for understanding and absolution." ${ }^{23}$ This is basically the idea of determinism. Still, Carson's notes do not reflect an awareness of the whole curve of the myth and his interpretation of Heaney's bog motif is based solely on the conclusion of one poem, "Punishment." His reaction to Heaney's poems was probably influenced by a sense of betrayal on learning about Heaney's move to the Republic of Ireland.

Heaney's idea to use the bog motif to address the present situation was based on "satisfactory imaginative parallels" between the two worlds, as he put it. ${ }^{24}$ This may be seen as an effort to come to terms with what is at hand, it is simply an act of reporting through ideas of similarity, meanwhile he is trying to remain neutral as much as possible, though according to Carson it is possible only at the price of falsifying reality. ${ }^{25}$ Still, the main aspects connecting the two worlds ar: violence (even barbarity) and the religious element concerning the territory, and these seem to be relevant through the filter of these "imaginative parallels."

\footnotetext{
${ }^{20}$ Quoted by Longley, p. 60.

${ }^{21}$ Deane, p. 69.

${ }^{22}$ Quoted by Richard Kirkland, "Paradigms of Possibility: Seamus Heaney." In: Michael Allen, ed. Seamus Heaney, p. 260.

${ }^{23}$ Quoted by Longley, p. 45.

${ }^{24}$ Quoted by Morrison, p. 63.

${ }^{25}$ Quoted by Kirkland, p. 260.
} 
Edna Longley refers to Heaney's perception of the Bog People in the volume North as being "contracted or "perfected,"” 26 suggesting the colouring of the imagination at work and acknowledging those imaginative parallels Heaney himself noted. However, in her view he sometimes "asks too much of his myth [...] as if 'archetypes' remain above or below argument." ${ }^{27}$ She also points out that there is not much evolution in the myth as suggested by the resemblances between the poems. ${ }^{28}$ She appreciates "The Tollund Man" as the real achievement; by going on with the theme "Heaney may have mistaken his initial epiphany for a literal signpost, when it was really a destination, a complete emotional curve that summed up profound feelings and wishes about the situation in Northern Ireland." ${ }^{29}$ However, the resemblances between the poems only work on the level of description - the implications show a definite evolution from "The Tollund Man" to "Kinship," and it is this development which creates a complete emotional curve rather than the poem offering the possibility of this.

The bog myth as a representation of the present is a highly personal interpretation, a personal vision, the attempt of Seamus Heaney to address the conflict of the present. The only charge which could be brought up against him is the lack of objectivity in bending the ancient elements of the myth to his liking to make it compatible with the ethos of the Troubles. (Yeats was accused of having done something very similar to this with Celtic mythology.) Still, the myth does not surrender easily. Heaney finds a potent symbol with "The Tollund Man." $\mathrm{He}$ gives a chance to the myth after the promise of the poem: he returns to it in North to see how it works itself out. However, "poems, like poets, are born and not made," as Frye declared; ${ }^{30}$ the direction began in the earlier poem is followed for a time but later, through his own dilemma of responding to the violence, he is compelled to move away from the mythic dimension and to recover the point of view associated with history.

Altogether, the bog myth points out that violence, regardless of whether in the Iron Age or in late twentieth-century Northern Ireland, defies rational explanation and mythicisation. There is a connection with religion, the world of faith, which suggests the dimension of irrationality rather than clear and plausible

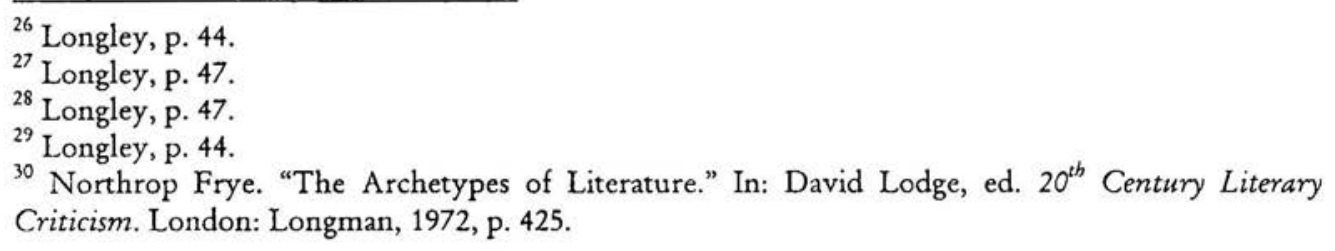


justification. As violence is a concept impossible to interpret in rational terms, the idea may appear that this may have been the ultimate aim of Heaney - to imply that there is no real solution to the problem. The final implication of "Kinship" is this as the objective distance of a writer of history is called for. In such a way Heaney himself can be the very first person to call attention to the limitations of his own myth. This would coincide with what Kiberd declares about Heaney: "the worst that can be said against Heaney always turns out to have been said already of himself by the artist within the poems."

The myth seems to have been closed down with the bog poems of the volume North as later poems move in different directions. The only potential connection to the bog myth is the poem entitled "Tollund" in the volume The Spirit Level. The poem is the account of a visit to the Danish bog in September 1994. The destination is the bog which yielded one of the ancient victims, the Tollund Man. Just as earlier, there are parallels between the bogland of Denmark and that of Ireland. Still, this poem is markedly different from the early ones. The first striking feature of this poem compared to the others is the use of rhyme. The atmosphere of the poem is peaceful, there is a relaxed contemplation in the elements of the landscape, and at the end the thought of being home emerges with the important notion of being now "free-willed again." The pilgrimage to Aarhus mentioned in "The Tollund Man" has now been made but the unhappiness of the time of nearly a quarter of a century earlier is replaced by the modest celebration of a new beginning.

\section{CONCLUSIONS}

Seamus Heaney's discovery of the bog produced a number of poems which aimed to provide a wider Northern European context to the contemporary violence in Northern Ireland. The poems are all parts of a wider framework of a myth while forming a myth themselves, and the construct of a myth embedded in another myth indicates the significance of the motif for Heaney. The concept of the bog offers a number of metaphoric connections; Heaney focuses on the parallels with memory and history.

Heaney's bog myth was not constructed along lines of conscious design from the outset. Rather, the poems reflect the reaction of someone contemplating the scene: the initial impression is that of similarity and this allows him to indulge

${ }^{31}$ Kiberd, p. 595. 
in an imaginative attempt at bringing together the two worlds of Iron Age Jutland and contemporary Northern Ireland. Contemplation, however, involves reflection as well and this compels Heaney to realise the problems of his project. The basis of similarity is violence connected with religion; this is an element irrational enough to defy any attempt at explanation - Heaney's intention to use the bog people as an objective correlative of the contemporary situation has to be reconsidered, and this reconsideration leads to the deconstruction of the myth.

Heaney's bog myth begins its life as an adequate analogue for the situation in twentieth-century Northern Ireland. However, despite his intention the myth begins to incorporate elements which are no longer compatible with his early assumptions of finding the dignity of religious sacrifice in the present conflict, and a dynamic relationship develops between Heaney and his creation. The dynamism of this relationship proves to be strong enough to deter him from his original direction, he is banished from the position of the myth-maker to that of the observer.

Heaney finds a potential analogue in the bog people of Iron Age Denmark for the conflict of the present. His role as a poet puts the responsibility of commenting on the present situation. In order to avoid choosing sides, Heaney examines the bog people of the Iron Age; his intention is to find some kind of explanation. The bog yields bodies, even a culture with a fertility religion but it is reluctant to provide more - just as the bog only releases the excess water, the fundamentals of violence remain buried.

Though the bog yields no explanation for the violence, Heaney recognises the difference between the ritual sacrifice of the Iron Age and the sectarian violence of the twentieth century. The poems brought together under the heading 'climax,' meaning the moments of most extreme tension yielding a new direction, mark an important phase in the development of the myth. However, with a backward look on the whole curve of the motif, the poem preceding the climax, "Bog Queen," carries a significant suggestion: the vegetation having overgrown the scene is an indication of the process in which nature subdues civilisation, and on a metaphoric level, the instinctive and uncontrolled violence replaces the control of civilisation over violence through religious ritual. The opposition between uncontrolled violence and religious ritual is the basic dilemma Heaney discovers and this is already a fundamental issue of humanity. The dilemma remains a dilemma at the end of the sequence, and in this way the bog motif of Seamus Heaney as a means of addressing the conflict of the present is the confession of the poet that there is no rational explanation for the violence. 